\title{
The ratio of transforming growth factor- $\beta 1 /$ bone morphogenetic protein-7 in the progression of the epithelial-mesenchymal transition contributes to rat liver fibrosis
}

\author{
W.R. Bi ${ }^{1}$, G.T. Xu' ${ }^{2}$ L.X. $\mathrm{Lv}^{2}$ and C.Q. Yang ${ }^{3}$ \\ ${ }^{1}$ Department of Gastroenterology and Digestive Disease Institute, \\ Tongji Hospital Branch, Tongji University School of Medicine, Shanghai, China \\ ${ }^{2}$ Department of Stem Cells Laboratory, Tongji University School of Medicine, \\ Shanghai, China \\ ${ }^{3}$ Department of Gastroenterology and Digestive Disease Institute, \\ Tongji Hospital, Tongji University School of Medicine, Shanghai, China \\ Corresponding author: C.Q. Yang \\ E-mail: cqyang@tongji.edu.cn
}

Genet. Mol. Res. 13 (1): 1005-1014 (2014)

Received January 10, 2013

Accepted July 5, 2013

Published February 20, 2014

DOI http://dx.doi.org/10.4238/2014.February.20.2

\begin{abstract}
This study was designed to show whether rat liver epithelial cells could undergo epithelial-mesenchymal transition (EMT), thereby directly contributing to liver fibrosis. The role of the ratio of transforming growth factor- $\beta 1$ (TGF- $\beta 1$ )/bone morphogenetic protein-7 (BMP-7) was evaluated in the progression of EMT or mesenchymal-epithelial transition. Primary rat liver epithelial cells were stimulated with different ratios of TGF- $\beta 1 / \mathrm{BMP}-7$ and examined for evidence of transition to a mesenchymal or epithelial phenotype. Liver sections were labeled to detect antigens associated with liver epithelial cells [E-cadherin (E-cad)], EMT [fibroblast-specific protein-1 (FSP-1), vimentin], myofibroblasts $[\alpha$-smooth muscle actin $(\alpha-$ SMA $)$, and intracellular signal-transduction mediated by forming liver fibrosis undergo EMT, resulting in the formation of invasive fibroblasts; this process may be driven or impeded
\end{abstract}


by a response to local TGF- $\beta 1$ or BMP-7. BMP-7 downregulated $\alpha$-SMA and phosphorylated Smad2/3. Stimulation of cultured cells with TGF- $\beta 1$ induced the expression of pSmad2/3, FSP-1, and $\alpha$-SMA. Stimulation of cultured cells with BMP-7 induced the expression of E-cad. We demonstrated that the cells upregulated E-cad release compared with untreated cells, but TGF- $\beta 1$ was different. We found that the equilibrium of the ratio of TGF- $\beta 1 / \mathrm{BMP}-7$ was $1 / 10$. In summary, the mechanism for this process was not determined. Demonstration of the contribution of what the ratio of TGF- $\beta 1 /$ BMP-7 induced to EMT to the chronic liver diseases would provide a new basis for understanding pathogenesis and potential treatment.

Key words: TGF- $\beta 1$; BMP-7; Epithelial-mesenchymal transition; Rat; Liver fibrosis

\section{INTRODUCTION}

Epithelial-mesenchymal transition (EMT) is a critical developmental process that plays a central role in the formation and differentiation of multiple tissues and organs. Unlike the cytolytic model of epithelial cell death followed by fibroblast repopulation, EMT can only occur if liver epithelial cells survive to transform into invading fibroblasts following stimulation by micro-environmental factors such as transforming growth factor- $\beta 1$ (TGF- $\beta 1$ ) (Lee and Kay, 2012).

Although normal livers express low levels of TGF- $\beta 1$ mRNA and nuclear pSmad2/3,

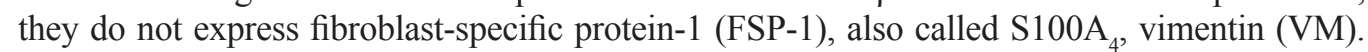
However, TGF- $\beta 1$ mRNA and nuclear $p S m a d 2 / 3$ are strongly expressed in damaged livers, which also express FSP-1. Cells in the liver fibrosis express both epithelial and mesenchymal markers together with high levels of TGF- $\beta 1$ mRNA (Jones et al., 2010). The proteomic features of EMT include loss of epithelial markers such as E-cadherin (E-cad), Zo-1, and cytokeratins, and the acquisition of fibroblast markers including FSP-1, VM, matrix metalloproteinase (MMP)-2 and MMP-9, $\alpha$-smooth muscle actin ( $\alpha$-SMA), collagens, and TGF- $\beta 1$ (Zhang et al., 2012). Induction of FSP-1 occurs sufficiently early to visualize epithelial cells in situ during the initial phases of EMT (Bi et al., 2012a). This protein can modify cell motility and growth through interactions with the cytoskeleton and the $\mathrm{C}$ terminus of $\mathrm{p} 53$ (Pegorier et al., 2010). In addition, induction of FSP-1 may promote invasive properties by upregulation of MMP expression. FSP-1 may play a central role during the induction and maintenance of the EMT phenotype (Jones et al., 2010).

In this study, primary liver epithelial cells were cultured with a range of stimuli, including TGF- $\beta 1 /$ BMP-7 (bone morphogenetic protein-7), to establish whether these can induce EMT or mesenchymal-epithelial transition (MET).

\section{MATERIAL AND METHODS}

\section{Animals and treatment}

\section{Animals}

Adult sex-matched ( $\mathrm{N}=20 \mathrm{each}) \mathrm{C} 57 \mathrm{BL}$ rats weighing $200 \pm 10.2 \mathrm{~g}$ were purchased 
from Tongji University Laboratories (Shanghai, China) and fed with a commercial diet and water. All animal experiments were performed according to the National Institutes of Health $(\mathrm{NIH})$ guidelines for the ethical care and use of laboratory animals, and the experimental protocol was approved by the Tongji Animal Care and Use Committee of China.

\section{Rat liver fibrosis models}

Forty adult numbered rats were sorted into liver fibrosis model and normal control groups. Twenty rats in the liver fibrosis group received intraperitoneal injections of $40 \% \mathrm{CCl}_{4}$ and olive oil admixture $(0.5 \mathrm{~mL} / 100 \mathrm{mg}$; Sigma-Aldrich, St. Louis, MO, USA) as previously described (Bi et al., 2012b). Rats were sacrificed after 8 weeks of treatment.

\section{RNA extraction and reverse transcription}

Total RNA was extracted from the rats with the TRIzol reagent kit (Invitrogen, Carlsbad, CA, USA) and used to determine BMP-7 and TGF- $\beta 1$ mRNA expression by real-time quantitative-polymerase chain reaction (RT-qPCR). All extracted RNA samples were dissolved in RNase-free water. The purity of the dissolved RNA was assessed using the $\mathrm{A}_{260} / \mathrm{A}_{280}$ ratio measured with a UV/VIS spectrophotometer (Nanodrop 2000/2000C, Gibco BRL, Paisley, manufacturers of HPLC, AR/GR and LR Grade Laboratory Reagents and Software USB Flash Drives Scanners Motherboards Network Cards Timepieces, USA) and the ratio was between 1.9 and 2.1 for all samples, indicating that the total RNA samples were of acceptable quality. The integrity of the RNA was determined via denaturing agarose gel electrophoresis. Total RNA was extracted following a conventional protocol and dissolved in $20 \mu \mathrm{L}$ RNase-free water.

RNA was reverse transcribed with a reaction mixture containing $6.5 \mu \mathrm{L}$ diethylpyrocarbonate- $\mathrm{H}_{2} \mathrm{O}, 4 \mu \mathrm{L} 5 \mathrm{X}$ buffer, $4 \mu \mathrm{L} 2.5 \mathrm{mM}$ dNTPs, $1 \mu \mathrm{L} 50 \mathrm{pM}$ oligo-(dT) $)_{18}, 2 \mu \mathrm{L} 5 \mathrm{U} /$ $\mu \mathrm{L}$ AMV, $0.5 \mu \mathrm{L} 40 \mathrm{U} / \mu \mathrm{L}$ RNase inhibitor, and $2 \mu \mathrm{L}$ RNA. The total reaction volume was 20 $\mu \mathrm{L}$. After gentle mixing, the solution was incubated for $60 \mathrm{~min}$ at $42^{\circ} \mathrm{C}$ and then for $15 \mathrm{~min}$ at $72^{\circ} \mathrm{C}$, followed by $2 \mathrm{~min}$ in an ice bath. Two controls were included in the RT reaction: the first prepared using all reagents except the RNA sample, for which an equivalent volume of water was substituted, and the second prepared using all reagents except RT. The controls underwent PCR procedures identical to those of the experimental samples. The complementary DNA product was stored at $-20^{\circ} \mathrm{C}$.

\section{RT-qPCR}

The primers used for amplification of BMP-7 and TGF- $\beta 1$ mRNA were determined using Primer Premier Version 5.0 (Premier Biosoft International, Canada) and verified using the Basic Local Alignment Search Tool (BLAST). All of the primers, including those for the glyceraldehyde-3-phosphate dehydrogenase (GAPDH)-encoding gene as an internal reference, were synthesized by Shanghai Sango Biological Engineering Technology \& Services Co. (China). Electrophoresis on $1.2 \%(\mathrm{w} / \mathrm{v})$ agarose gels was conducted to determine the quality and integrity of the primers. The sequence of the primers and the corresponding amplicon sizes were as follows: BMP-7, 5'-GAAAACAGCAGCAGTGACCA-3' (forward) and 5'-GGTGGCGTTCATGTAGGAGT-3' (reverse), 174 bp; TGF- $\beta 1$, 5'-CTAATGGTGGACCG CAACAAC-3' (forward) and 5'-CGGTTCATGTCATGGATGGTG-3' (reverse), $430 \mathrm{bp}$; 
GAPDH, 5'-ACCACAGTCCAGCCATCAC-3' (forward), 5'-TCCACCACCCTGTTGCTGT A-3' (reverse), 175 bp.

The complementary DNA obtained was further amplified using PCR in a $25-\mu \mathrm{L}$ reaction consisting of $1 \mu \mathrm{L}$ RT reaction solution, $12.5 \mu \mathrm{L} 2 \mathrm{X}$ master mix (Shanghai Wonhon Biotechnology Company), $1 \mu \mathrm{L} 20 \mathrm{pM}$ forward primer, $1 \mu \mathrm{L} 20 \mathrm{pM}$ reverse primer, and $9.5 \mu \mathrm{L}$ sterilized $\mathrm{H}_{2} \mathrm{O}$. The reaction substrates were mixed by gently flicking the bottom of each tube. PCR amplification was performed for 35 cycles $\left(95^{\circ} \mathrm{C}\right.$ for $30 \mathrm{~s} ; 59^{\circ} \mathrm{C}$ for $30 \mathrm{~s} ; 72^{\circ} \mathrm{C}$ for $\left.30 \mathrm{~s}\right)$ for GAPDH and 35 cycles $\left(95^{\circ} \mathrm{C}\right.$ for $30 \mathrm{~s} ; 58^{\circ} \mathrm{C}$ for $30 \mathrm{~s} ; 72^{\circ} \mathrm{C}$ for $\left.30 \mathrm{~s}\right)$ for all other amplicons. Reactions were completed with a final extension at $72^{\circ} \mathrm{C}$ for $10 \mathrm{~min}$. For each $5 \mu \mathrm{L}$ of sample, PCR amplicons were mixed gently with $3 \mu \mathrm{L}$ fluorochrome, protected from light for $10 \mathrm{~min}$, and then visualized on a $1.2 \%$ agarose gel with a Multilmage Light System (Shanghai Tianneng Biotechnology Company).

\section{In vitro differentiation of mesoangioblasts}

Cells were treated with $5 \mathrm{ng} / \mathrm{mL}$ TGF- $\beta 1$, with or without pretreatment with the neutralizing antibody anti-TGF- $\beta 1(250 \mu \mathrm{g} / \mathrm{mL}$; R\&D Systems), in medium supplemented with $2 \%$ horse serum for 5 to 7 days (TGF- $\beta 1$ was added every other day) and then fixed and stained with an antibody recognizing the $\alpha$-SMA antibody. Alternatively, mesoangioblasts transiently transfected with Noggin or Chordin expression vectors, or mock transfected mesoangioblasts, were treated with $100 \mathrm{ng} / \mathrm{mL}$ BMP-7 in complete medium for 5 days (BMP-7 was added every other day), then fixed and stained for alkaline phosphatase. For mineralized nodule assays, mesoangioblasts were maintained in growth medium supplemented with $50 \mu \mathrm{g} / \mathrm{mL}$ ascorbic acid, $10 \mathrm{mM} \beta$-glycerol phosphate, $10 \mathrm{nM}$ dexamethazone, and $100 \mathrm{ng} / \mathrm{mL}$ BMP-7 for 25 days. At the end of the culture period, cultures were stained for alkaline phosphatase, and mineral deposition was assessed using the von Kossa method, according to standard procedures. For adipocyte differentiation, cells were first grown in Dulbecco's modified Eagle's medium (DMEM), $10 \%$ fetal calf serum, $1 \mathrm{mM}$ glutamine, $500 \mu \mathrm{M}$ isobutylmethylxanthine, $1 \mu \mathrm{M}$ dexamethasone, and $1 \mu \mathrm{g} /$ $\mathrm{mL}$ insulin. After 2 days, cells were transferred to adipocyte growth medium (DMEM containing $10 \%$ fetal calf serum, $1 \mathrm{mM}$ glutamine, $25 \mathrm{mM}$ glucose, $0.5 \mathrm{mM}$ glutamine, and $1 \mu \mathrm{g} / \mathrm{mL}$ insulin) and re-fed every 2 days. Differentiation of mesoangioblasts into mature adipocytes was confirmed by Red Oil staining.

The proportion of cells differentiating to different cell types was calculated by counting the cells expressing the appropriate differentiation markers against the total number of cells. An average value was determined by counting cells in at least 10 microscopic fields, for at least 3 different experiments.

\section{Immunofluorescence}

Immunofluorescence of cell culture antibodies used in this study, and their working dilutions, were the following: anti- $\alpha$-SMA mAb (1:350; Sigma-Aldrich), anti-TGF- $\beta 1 \mathrm{mAb}$ (1:500; Sigma-Aldrich), anti-BMP-7 mAb (1:300), anti-E-cad mAb (1:400), anti-FSP-1 mAb (1:300; Sigma-Aldrich), anti-VM mAb (1:400; Sigma-Aldrich), and anti-GFAP polyclonal antibody (1:200; Dako, Carpinteria, CA, USA).

Primary antibodies were reacted with appropriate secondary antibodies (Molecular Probes and Jackson Immuno Research), conjugated with TRITC, Alexa 594, or Alexa 488 for fluorescence detection. 


\section{Western blotting}

Whole cell proteins $(20 \mu \mathrm{g})$ were separated by PAGE and transferred to nylon membranes. Primary antibodies were as follows: anti- $\alpha$-SMA (1:2000; Dako), anti-TGF- $\beta 1$ (1:2000; Santa Cruz Biotechnology, Santa Cruz, CA, USA), anti-VM (1:2000 dilution), anti-BMP-7 (1:1500; Cell Signaling Technology, Danvers, MA, USA), anti-FSP-1 (1:2000; Santa Cruz Biotechnology), and anti-E-cad (1:2000; Sigma-Aldrich). Appropriate secondary antibodies were used with antigens demonstrated by enhanced chemiluminescence (Pierce Biotechnology, Rockford, IL, USA).

\section{Statistical analyses}

All results are reported as means \pm SD and analyzed with SPSS version 13.0 (Chicago, IL, USA). Differences between groups were analyzed using the Student-Newman-Keuls post hoc test of one-way analysis of variance (ANOVA), and differences between groups were evaluated using the paired-sample $t$-test. The significance level was set at $\mathrm{P}<0.05$ or $\mathrm{P}<$ 0.001 , using two-tailed testing.

\section{RESULTS}

\section{General remarks and groups}

None of the animals died during the study period. A total of 50 adult numbered rats were randomly sorted into 4 groups: i) normal control group: 5 rats received intraperitoneal injections of olive oil $(0.5 \mathrm{~mL} / 100 \mathrm{mg})$ twice each week; ii) liver fibrosis model group: 10 rats received intraperitoneal injections of $40 \% \mathrm{CCl}_{4}$ and olive oil admixture $(0.5 \mathrm{~mL} / 100 \mathrm{mg})$; iii) TGF- $\beta 1 /$ BMP-7-treated groups: 35 rats received intraperitoneal injections of $40 \% \mathrm{CCl}_{4}$ and olive oil admixture $(0.5 \mathrm{~mL} / 100 \mathrm{mg})$ twice each week, and each group consisted of 5 rats according to the following different ratios of TGF- $\beta 1 / \mathrm{BMP}-7: 1 / 1(50 / 50 \mu \mathrm{g} / \mathrm{kg}), 1 / 2.5(50 / 125$ $\mu \mathrm{g} / \mathrm{kg}), 1 / 5(50 / 250 \mu \mathrm{g} / \mathrm{kg}), 1 / 10(50 / 500 \mu \mathrm{g} / \mathrm{kg}), 1 / 15(50 / 750 \mu \mathrm{g} / \mathrm{kg}), 1 / 20(50 / 1000 \mu \mathrm{g} / \mathrm{kg})$, $1 / 30(50 / 1500 \mu \mathrm{g} / \mathrm{kg})$, simultaneously. The rats were sacrificed after 8 weeks of treatment.

\section{Ratio of TGF- $\beta 1 /$ BMP-7}

The immunofluorescence method displayed the protein E-cad expression for different ratios of TGF- $\beta 1$ /BMP-7, from $1 / 1$ to $1 / 30$, in $\mathrm{CCl}_{4}$-induced rat liver fibrosis, and the optimal ratio of TGF- $\beta 1 /$ BMP-7 was $1 / 10$. At a ratio of $1 / 1$, there was scarce protein expression of E-cad cells. As the ratio of TGF- $\beta 1 /$ BMP-7 increased, protein expression of E-cad cells increased. When the ratio of TGF- $\beta 1 / \mathrm{BMP}-7$ exceeded $1 / 10$, protein expression of E-cad cells started to decrease. When the ratio of TGF- $\beta 1 / \mathrm{BMP}-7$ was $1 / 30$, protein expression of E-cad cells was markedly reduced. The balance of the ratio of TGF- $\beta 1 / \mathrm{BMP}-7$ was $1 / 10$ (Figure 1). The expression levels of $\alpha$-SMA and E-cad mRNA relative to GAPDH occurred in different ratios of TGF- $\beta 1 /$ BMP-7 from $1 / 1$ to $1 / 20$ during EMT; as the ratio of TGF- $\beta 1 /$ BMP-7 increased, expression of E-cad mRNA increased. When the ratio of TGF- $\beta 1 / B M P-7$ exceeded $1 / 10$, expression of E-cad mRNA started to decrease. This decrease was reversed for the expression of $\alpha$-SMA mRNA (Figure 2). 

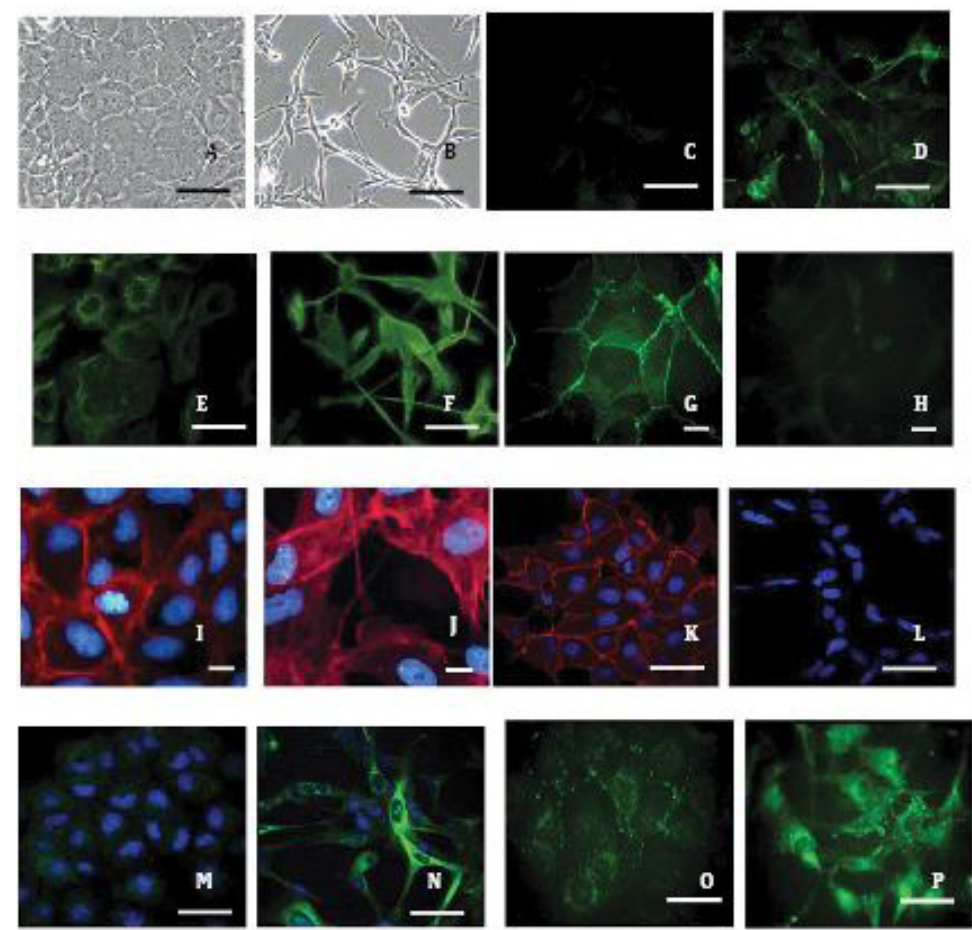

Figure 1. Protein expression of E-cad during different ratios of TGF- $\beta 1 / \mathrm{BMP}-7$ from $1 / 1$ to $1 / 30$ in $\mathrm{CCl}_{4}$-induced rat liver fibrosis (immunofluorescence method). A. and B. Phase image contrast, where A is the contrast group and B is the liver fibrosis group; ratios of TGF- $\beta 1 /$ BMP-7 were $1 / 1(\mathbf{C}$ and $\mathbf{D}), 1 / 2.5(\mathbf{E}$ and $\mathbf{F}), 1 / 5(\mathbf{G}$ and $\mathbf{H}), 1 / 10(\mathbf{I}$ and $\mathbf{J})$, $1 / 15(\mathbf{K}$ and $\mathbf{L}), 1 / 20(\mathbf{M}$ and $\mathbf{N}), 1 / 30(\mathbf{O}$ and $\mathbf{P}) ;(\mathrm{D}-\mathrm{P})$ protein expression of $\mathrm{E}$-cad in $\mathrm{CCl}_{4}$-induced rat liver fibrosis during different ratios of TGF- $\beta 1 / \mathrm{BMP}-7$ from $1 / 1$ to $1 / 30$; (I-L) DAPI E-cad cell nuclear staining blue fluorescence, cell membrane staining red fluorescence in $1 / 10$ and $1 / 15$ ratios of TGF- $31 / B M P-7$; (E-H and M-P) DAPI E-cad cell nuclear staining blue fluorescence, cell membrane staining green fluorescence in 1/2.5,1/5,1/20, and 1/30 ratios of TGF-B1/BMP-7. Scale $=35 \mu \mathrm{m}$. Normal control group: 5 rats received intraperitoneal injections of olive oil $(0.5$ $\mathrm{mL} / 100 \mathrm{mg}$ ) twice every week. Liver fibrosis model group: 10 rats received intraperitoneal injections of $40 \% \mathrm{CCl}_{4}$ and olive oil admixture $(0.5 \mathrm{~mL} / 100 \mathrm{mg})$. TGF- $\beta 1 / B M P-7-t r e a t e d$ groups: 35 rats received intraperitoneal injections of $40 \% \mathrm{CCl}_{4}$ and olive oil admixture $(0.5 \mathrm{~mL} / 100 \mathrm{mg})$ twice every week and each group of 5 rats according to the following different ratios of TGF- $\beta 1 / B M P-7: 1 / 1(50 / 50 \mu \mathrm{g} / \mathrm{kg}), 1 / 2.5(50 / 125 \mu \mathrm{g} / \mathrm{kg}), 1 / 5(50 / 250 \mu \mathrm{g} / \mathrm{kg}), 1 / 10$ $(50 / 500 \mu \mathrm{g} / \mathrm{kg}), 1 / 15(50 / 750 \mu \mathrm{g} / \mathrm{kg}), 1 / 20(50 / 1000 \mu \mathrm{g} / \mathrm{kg}), 1 / 30(50 / 1500 \mu \mathrm{g} / \mathrm{kg})$ at the same time.

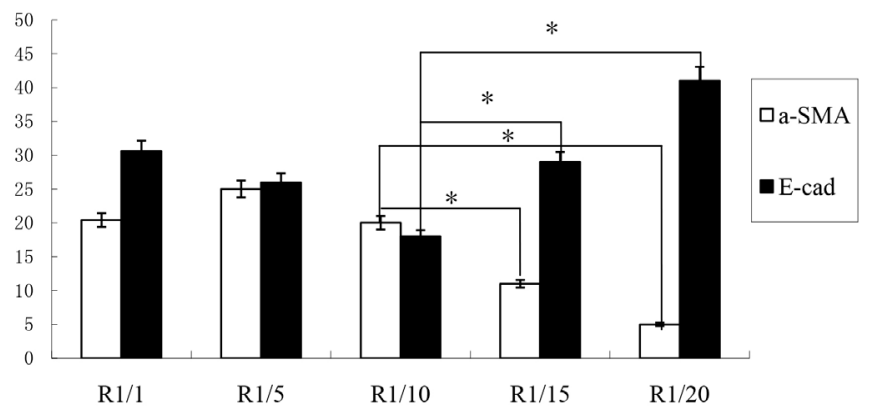

Figure 2. Expression levels of $\alpha$-SMA and E-cad mRNA relative to GAPDH in different ratios of TGF- $\beta 1 / \mathrm{BMP}-$ 7 from $1 / 1$ to $1 / 20$ during epithelial-mesenchymal transition. After the ratio of TGF- $\beta 1 / B M P-7$ exceeded $1 / 10$, expression of E-cad mRNA started to decrease and the expression of $\alpha$-SMA mRNA increased $(* \mathrm{P}<0.05)$. 


\section{Protein expression of E-cad and $\alpha$-SMA}

The present study demonstrated that rats treated with TGF- $\beta 1$ had increased hepatic fibrosis in $\mathrm{CCl}_{4}$-induced liver injury. This was accompanied by increased expression of hepatic fibrosis mesenchymal markers, including $\alpha$-SMA, but repression of E-cad. This observation was reversed in rats treated with BMP-7. Protein expression of E-cad cells started to decrease, and $\alpha$-SMA cells increased significantly in rat hepatic tissue with a TGF- $\beta 1 /$ BMP-7 ratio of $1 / 10(50 / 500 \mu \mathrm{g} / \mathrm{kg}$ ) (Figure 3). Gel electrophoresis of RT-PCR products of E-cad and $\alpha$-SMA in $\mathrm{CCl}_{4}$-induced rat liver fibrosis during EMT from 1-D to 3-D, using different ratios of TGF- $\beta 1$ /BMP-7, also confirmed this observation (Figure 4).
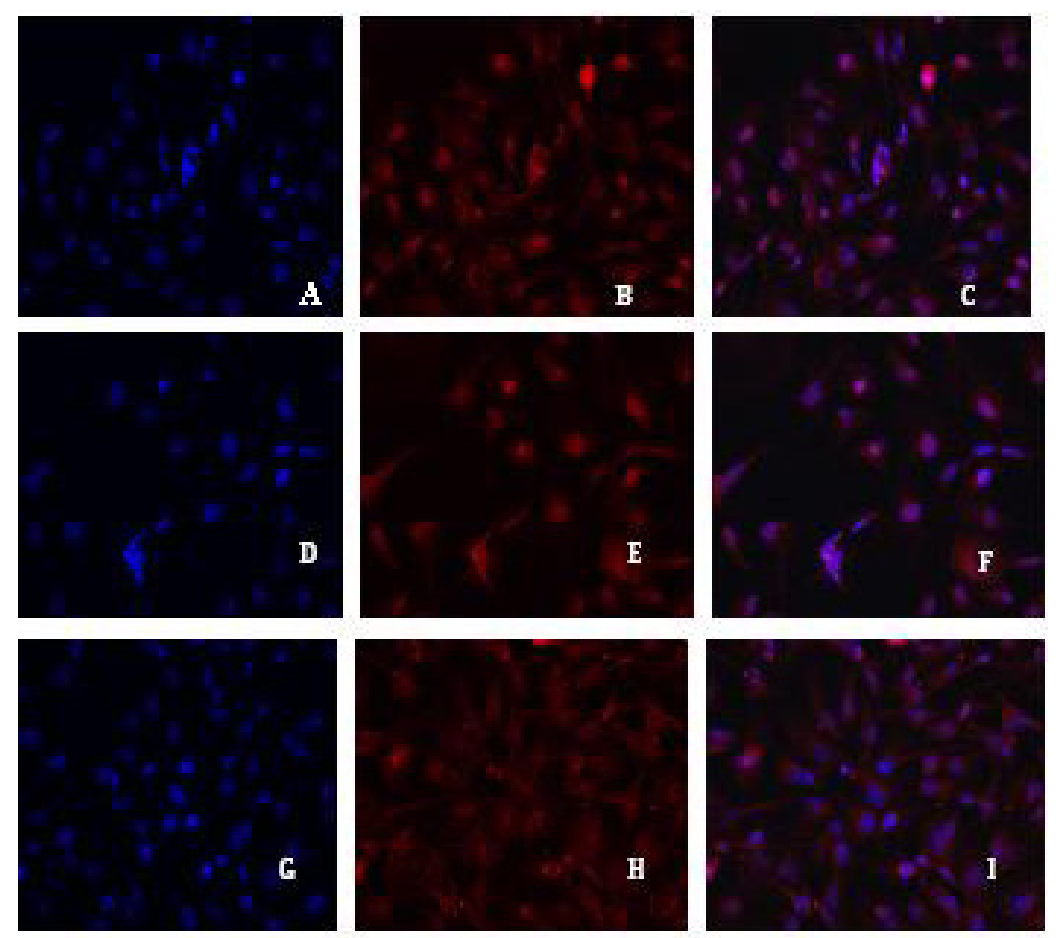

Figure 3. Protein expression of E-cad and $\alpha$-SMA in rat hepatic tissue with TGF- $\beta 1 /$ BMP-7-treated $1 / 10(50 / 500$ $\mu \mathrm{g} / \mathrm{kg}$ ) (immunofluorescence method). A. B. C. Protein expression of normal control group; D. E. F. protein expression of E-cad in $\mathrm{CCl}_{4}$-induced rat liver fibrosis; G. H. I. protein expression of $\alpha$-SMA in $\mathrm{CCl}_{4}$-induced rat liver fibrosis; A. D. G. protein expression of nucleus of control, E-cad and $\alpha$-SMA with blue fluorescence; B. E. H. protein expression of cytomembrane of control, E-cad and $\alpha$-SMA with red fluorescence; C. F. I. protein expression of control, E-cad and $\alpha$-SMA with merged blue and red fluorescence. Normal control group: 5 rats received intraperitoneal injections of olive oil $(0.5 \mathrm{~mL} / 100 \mathrm{mg})$ twice every week; TGF- $\beta 1 / \mathrm{BMP}-7$-treated groups: 5 rats received intraperitoneal injections of $40 \% \mathrm{CCl}_{4}$ and olive oil admixture $(0.5 \mathrm{~mL} / 100 \mathrm{mg})$ twice every week and TGF- $\beta 1 / B M P-7$ with $1 / 10(50 / 500 \mu \mathrm{g} / \mathrm{kg})$ at the same time.

\section{Expression of FSP-1 and E-cad proteins}

Western blotting showed protein expression of E-cad and FSP-1 for different ratios of TGF- $\beta 1 / \mathrm{BMP}-7$ from $1 / 1$ to $1 / 30$, in $\mathrm{CCl}_{4}$-induced rat liver fibrosis, and the optimum ratio 

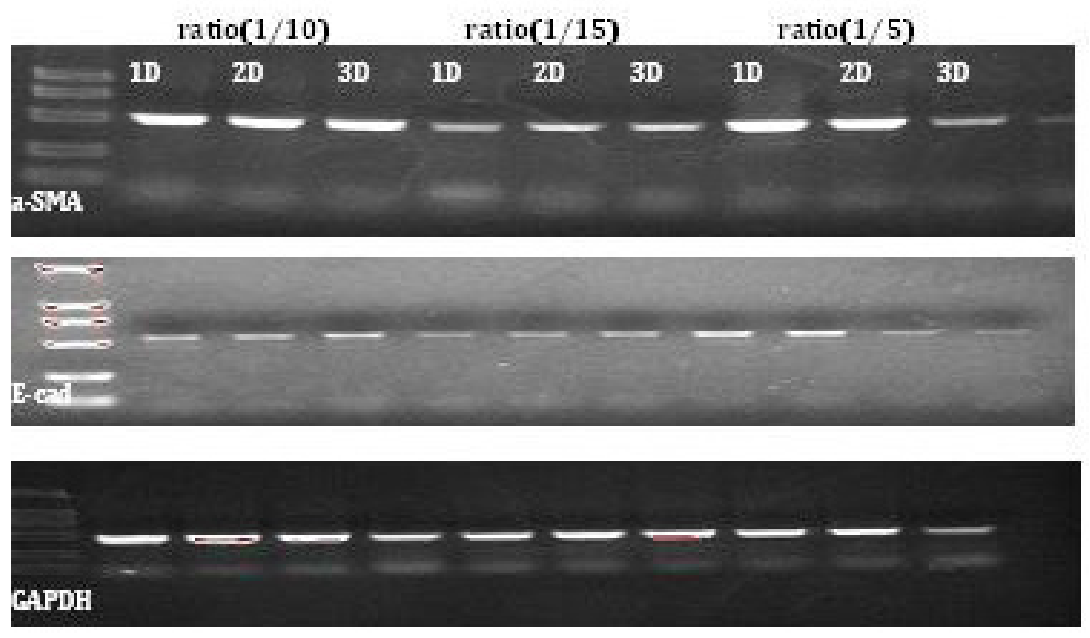

Figure 4. Gel electrophoresis of RT-PCR products of E-cad and $\alpha$-SMA in $\mathrm{CCl}_{4}$-induced rat liver fibrosis during EMT from 1-D to 3-D in different ratios of TGF- $\beta 1 / \mathrm{BMP}-7$. Fifteen rats received intraperitoneal injections of $40 \%$ $\mathrm{CCl}_{4}$ and olive oil admixture $(0.5 \mathrm{~mL} / 100 \mathrm{mg})$ twice every week and each group of 5 rats according to the following different ratios of TGF- $\beta 1 /$ BMP-7: $1 / 5(50 / 250 \mu \mathrm{g} / \mathrm{kg}), 1 / 10(50 / 500 \mu \mathrm{g} / \mathrm{kg}), 1 / 15(50 / 750 \mu \mathrm{g} / \mathrm{kg})$ at the same time.

of TGF- $\beta 1 / \mathrm{BMP}-7$ was $1 / 10$. At a ratio of $1 / 1$, protein expression of E-cad was scarce. As the ratio of TGF- $\beta 1 /$ BMP-7 increased, protein expression of E-cad increased. When the ratio of TGF- $\beta 1 /$ BMP-7 exceeded 1/10, protein expression of E-cad cells started to decrease, and this trend was reversed for expression of FSP-1 (Figure 5).

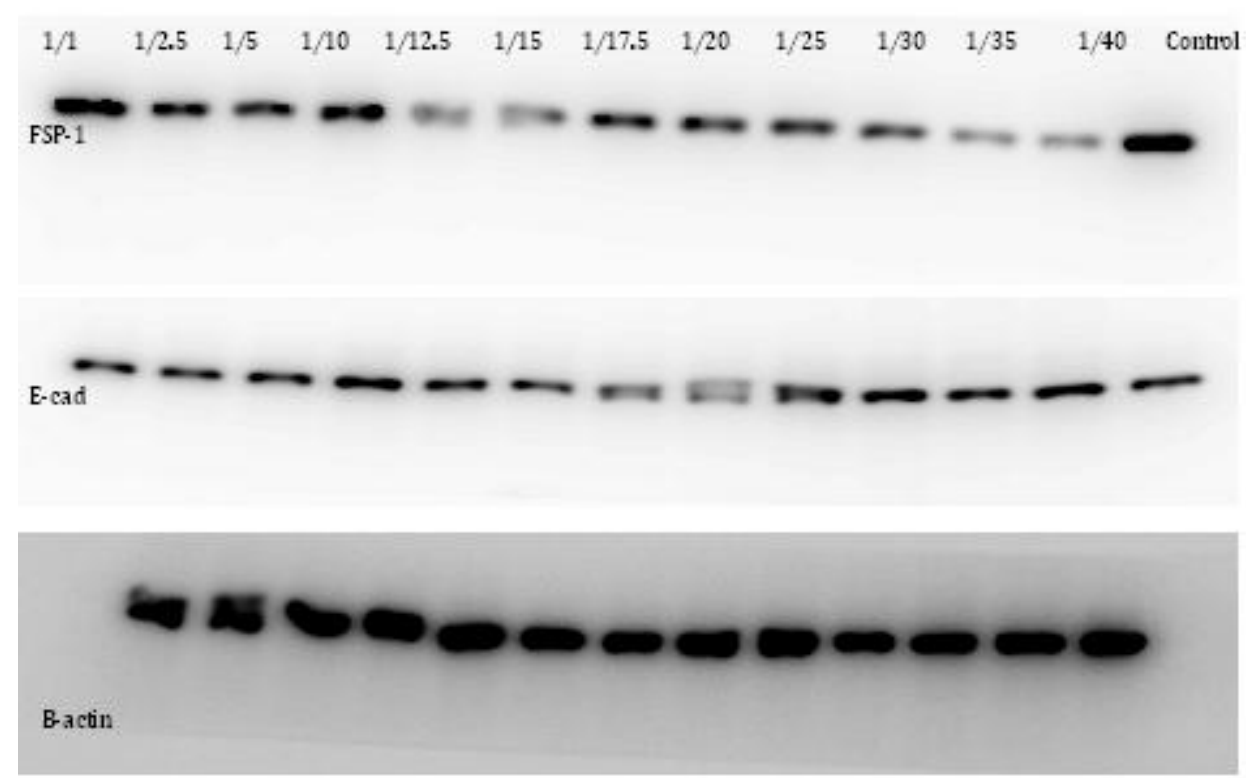

Figure 5. Western blotting analysis of the expression of FSP-1 and E-cad protein in $\mathrm{CCl}_{4}$-induced rat liver fibrosis treated with different ratios of TGF- $\beta 1 / \mathrm{BMP}-7$ from 1/1 to 1/40 during epithelial-mesenchymal transition. 


\section{DISCUSSION}

In this study, we combined data from immunohistochemical and in situ hybridization studies of rat liver tissues with results from cell culture experiments to provide strong evidence that TGF- $\beta 1$ contributed significantly to liver fibrosis. We also showed that BMP-7 blocked the TGF- $\beta 1$-induced EMT on liver cell phenotypic markers: E-cad expression was significantly increased, while the expression of hepatic interstitial cell phenotypic markers $\alpha$-SMA and FSP-1 was significantly reduced.

Immunofluorescence and Western blotting showed protein expression of E-cad for different ratios of TGF- $\beta 1 / \mathrm{BMP}-7$ from $1 / 1$ to $1 / 30$, in $\mathrm{CCl}_{4}$-induced rat liver fibrosis, and the optimal ratio of TGF- $\beta 1 / \mathrm{BMP}-7$ was $1 / 10$. At a ratio of $1 / 1$, protein expression of E-cad cells was scarce. As the ratio of TGF- $\beta 1 /$ BMP-7 increased, protein expression of E-cad cells increased. When the ratio of TGF- $\beta 1 / \mathrm{BMP}-7$ exceeded $1 / 10$, protein expression of $\mathrm{E}$-cad started to decrease. When the ratio of TGF- $\beta 1 / \mathrm{BMP}-7$ was $1 / 30$, protein expression of E-cad cells showed a marked reduction. In conclusion, the optimum balance was achieved when the ratio of TGF- $\beta 1 /$ BMP-7 was $1 / 10$.

In the resting state, cultured liver epithelial cells have an epithelioid morphology, but neither FSP-1 nor $\alpha$-SMA has this morphology (Luo et al., 2012). Treatment with TGF- $\beta 1$ induces $\operatorname{Smad} 2 / 3$ phosphorylation with translocation of the corresponding phosphoproteins to the nucleus. Importantly, the stimulated cells uniformly adopted a fibroblastic morphology, with increased cytoplasmic expression of EMT markers ( $\alpha$-SMA and FSP-1). The stimulated cells also acquired high levels of organized $\alpha$-SMA within their cytoplasm, indicating transdifferentiation from epithelial cells to mature myofibroblasts, significantly enhancing the potential to invade the basement membrane-like matrix (Garcia de Herreros and Baulida, 2012). TGF- $\beta 1$-induced liver fibrosis epithelial cells clearly acquire some mesenchymal antigens and lose epithelial markers (Bramlage et al., 2010). This change is accompanied by an increased motility and matrix invasion in vitro, consistent with the observations in this study.

BMPs represent a large class of multifunctional growth factors involved in a major developmental signaling pathway critical for embryogenesis and tissue generation in organs, including the kidney and lungs (Lim et al, 2011). BMP-7 has inhibitory effects because it is able to counteract TGF- $\beta 1$-induced fibrotic effects in vitro and reverse established fibrosis in organs as diverse as the kidney, heart, and colon (Mizuiri et al., 2011). Liver epithelial cells and other cells in normal livers (except for occasional inflammatory cells) express FSP-1, suggesting that resident fibroblasts are of a different lineage compared with local epithelial cells. However, liver fibrosis cells with an epithelial phenotype showed marked induction of FSP-1 and $\alpha$-SMA ( $\mathrm{Li}$ et al., 2012). In addition, BMP-7-induced expression of E-cad was noted in liver fibrosis during MET. E-cad that remained was fragmented and was redistributed to the cytoplasm. This suggests that, at least in these diseases, the development of liver fibrosis is associated with local induction of an EMT process (Gomez-Alamillo et al., 2010), further emphasizing the importance of the TGF- $\beta 1 /$ BMP-7 ratio for EMT.

Demonstration of the increased expression ratio of TGF- $\beta 1 / \mathrm{BMP}-7$ in some cells with a corresponding change in fibroblastic morphology also suggests the presence of some cells at the EMT stage after the TGF- $\beta 1$-induced liver fibrosis. Hence, the absence of a TGF- $\beta 1 /$ BMP-7 expression ratio-induced change within the liver epithelium might indicate that cells are undergoing EMT and are migrating from this tissue before commencing $\alpha$-SMA and FSP1 expression. Differences in the expression of individual antigens after the induction of EMT 
further emphasize the importance of the detection of the TGF- $\beta 1 / B M P-7$ ratio in epithelial cells, already one of the markers of this transition process. We found that the TGF- $\beta 1 / \mathrm{BMP}-7$ ratio of 1/10 directly increased cell motility through modification of actin function, suggesting the expression of liver cell phenotypic markers; E-cad expression was significantly increased and the expression of hepatic interstitial cell phenotypic markers $\alpha$-SMA and FSP- 1 was significantly reduced. Primary liver epithelial cells will be cultured with a range of stimuli, including TGF $\beta-1 /$ BMP-7, to establish whether these signals can induce EMT or MET.

\section{ACKNOWLEDGMENTS}

Research supported by a grant from the National Natural Science Foundation of China (\#81070343) and the Shanghai Innovation Program (\#12431901002).

\section{REFERENCES}

Bi WR, Yang CQ and Shi Q (2012a). Transforming growth factor-beta1 induced epithelial-mesenchymal transition in hepatic fibrosis. Hepatogastroenterology 59: 1960-1963.

Bi WR, Jin CX, Xu GT and Yang CQ (2012b). Bone morphogenetic protein-7 regulates Snail signaling in carbon tetrachloride-induced fibrosis in the rat liver. Exp. Ther. Med. 4: 1022-1026.

Bramlage CP, Tampe B, Koziolek M, Maatouk I, et al. (2010). Bone morphogenetic protein (BMP)-7 expression is decreased in human hypertensive nephrosclerosis. BMC Nephrol. 11: 31.

Garcia de Herreros A and Baulida J (2012). Cooperation, amplification, and feed-back in epithelial-mesenchymal transition. Biochim. Biophys. Acta 1825: 223-228.

Gomez-Alamillo C, Benito-Hernandez A, Ramos-Barron MA, Agueros C, et al. (2010). Analysis of urinary gene expression of epithelial-mesenchymal transition markers in kidney transplant recipients. Transplant. Proc. 42: 2886-2888.

Jones CN, Tuleuova N, Lee JY, Ramanculov E, et al. (2010). Cultivating hepatocytes on printed arrays of HGF and BMP7 to characterize protective effects of these growth factors during in vitro alcohol injury. Biomaterials 31: 5936-5944.

Lee JG and Kay EP (2012). NF-kappaB is the transcription factor for FGF-2 that causes endothelial mesenchymal transformation in cornea. Invest. Ophthalmol. Vis. Sci. 53: 1530-1538.

Li L, Hu Z, Li W, Hu M, et al. (2012). Establishment of a standardized liver fibrosis model with different pathological stages in rats. Gastroenterol. Res. Practice 2012: 560345.

Lim M, Chuong CM and Roy-Burman P (2011). PI3K, Erk signaling in BMP7-induced epithelial-mesenchymal transition (EMT) of PC-3 prostate cancer cells in 2- and 3-dimensional cultures. Horm. Cancer 2: 298-309.

Luo W, Fang W, Li S and Yao K (2012). Aberrant expression of nuclear vimentin and related epithelial-mesenchymal transition markers in nasopharyngeal carcinoma. Int. J. Cancer 131: 1863-1873.

Mizuiri S, Hemmi H, Arita M, Tai R, et al. (2011). Effluent markers related to epithelial mesenchymal transition with adjusted values for effluent cancer antigen 125 in peritoneal dialysis patients. Int. J. Nephrol. 2011: 261040.

Pegorier S, Campbell GA, Kay AB and Lloyd CM (2010). Bone morphogenetic protein (BMP)-4 and BMP-7 regulate differentially transforming growth factor (TGF)- $\beta 1$ in normal human lung fibroblasts (NHLF). Respir. Res. 11: 85.

Zhang Y, Wei J, Wang H, Xue X, et al. (2012). Epithelial mesenchymal transition correlates with CD24+CD44+ and CD133+ cells in pancreatic cancer. Oncol. Rep. 27: 1599-1605. 